\author{
Jarosław Kazimierczak \\ University of Łódź \\ Institute of Urban Geography and Tourism Studies \\ 90-142 Łódź, ul. Kopcińskiego 31 \\ j.kazimierczak@geo.uni.lodz.pl
}

\title{
THE INFLUENCE OF THE REVITALIZATION OF FORMER INDUSTRIAL URBAN AREAS ON NEW URBAN AND TOURISM SPACES: CASE STUDIES OF MANCHESTER AND LYON ${ }^{1}$
}

\begin{abstract}
The purpose of this article is the identification of changes to urban and tourism space due to the revitalization of the industrial wastelands in selected cities of Western Europe. The first section presents problematic aspects of this issue whereas the second constitutes empirical research on two cities: Lyon and Manchester. Typical characteristics of these cities include their differing 'tourism biographies' as well as their diverse spatial and functional structures. Furthermore, different ways of implementing the revitalization of central area former industrial land have been followed which have been extremely significant in forming the new tourism space in both cities.
\end{abstract}

Key words: revitalization, industrial wasteland, urban and tourism space, Lyon, Manchester.

\section{RESEARCH ISSUE}

In the $20^{\text {th }} \mathrm{c}$. the relocation of industry was a consequence of changes in technology, the organization of production and developments in transportation in the industrialized cities of Western Europe. These had a major influence on producing large areas of former industrial wasteland in cities which have become an integral part of their spatial and functional structure. The existence of such land became an important 'cognitive' value of urban space, and had a huge effect on the degradation of the cityscape.

Since the 1960s, revitalization has been seen as a method of renovating the degraded parts of cities. According to KACZMAREK (2010, p. 8) "the purpose of the re-structuring processes of urban space is a sequence of planned actions which contribute to economic revival and change the special and functional structure of degraded areas". Other researchers dealing with this issue present similar opinions, for example. DOMAŃSKI (2000), GASIDŁO (1998), LORENS (2005, 2007, 2010), LORENS \& MARTYNIUK-PĘCZAK (2009), MARKOWSKI \& STAWASZ (2007), MIRONOWICZ \& OSSOWICZ (2005), ZIOBROWSKI \& JERCZEWSKI (2009), ZIOBROWSKI et al. (2000). Revitalization refers to economic, social, cultural and spatial aspects (KACZMAREK 2001) and has a significant influence on the image of a city among its citizens and in addition affects the external image through promotional and marketing activity. Numerous planning and market- ing projects have increased the attractiveness of the city. Therefore, revitalization of intra-urban industrial waste land may lead to the transformation of urban and tourism space.

Tourism space has been the subject of much deliberation in the literature (including DEWAILLY 1996, KOWALCZYK-ANIOE 2006, LATOSIŃSKA 2006, LISOWSKI 2003, LISZEWSKI 1995, 1999, 2005, 2006a, 2006b, 2009a, 2009b, 2009c, 2009d, LISZEWSKI \& BACHVAROV 1998, LOZATO-GIOTART 2003, MEYER 2004, MiOSSEC 1976, OPPERMANN 1993, STALSKI 1984, WARSZYŃSKA \& JACKOWSKI 1978, WŁODARCZYK 2005, 2006a, 2006b, 2007, 2009 and others) and some have referred to the revitalization of space through tourism (BRADBURY 1993, IMRIE \& THOMAS 1993, GIBSON 1997, KACZMAREK \& LISZEWSKI 1997, PRZYBYSZEWSKA-GUDELIS 1997). Urban space and tourism space are geographical subspaces, according to LISZEWSKI (1999) the first is characterized by specific organization whereas the second can be recognized on the basis of functional criteria. This means that they are identified on the basis of conceptually different criteria and may therefore be found in the same part of general geographical space. A feature of both tourism and urban spaces is variation over time while revitalization by influencing spatial and functional transformations is dynamic. As a result, it can be claimed that, depending on the subject and extent of change accomplished in the 
framework of revitalization, the process can affect the formation of new urban and tourism spaces or modify those existing.

Manchester and Lyon both used to be powerful centres of the textile industry. As a consequence of the collapse of industry in these cities industrial wastelands were formed in central areas, a major problem for municipal authorities as the industrial wasteland occupied some of the most central parts. The industrial wasteland being close to the centre led to the image of the whole city, which often had great cultural and historical value, being devalued. On the other hand, undeveloped space here constitutes an opportunity for generating attractive urban spaces which could increase the aesthetic, scenic and utility value of neighbouring areas. What is more, their spatial and functional transformation would enable the expansion and strengthening of the tourism offer of the historical centre itself.

Lyon and Manchester are cities where industry has played a variety of roles in their socio-economic and historical structures. Therefore, the tangible heritage of the industrial epoch, contributing to the formation of the identity of these cities, is now being exposed differently in urban space. The significance of the postindustrial facilities in the revitalized zones depends on the new functional profile designed for those areas. Similarly, newly built contemporary buildings contribute to a new architectural and urban image. As a result, the transformations of degraded areas determine the tourism space of both newer and older parts of the central area.

Taking into account the above considerations, it can be claimed that the complexity of urban space as well as the shape of the industrial wasteland, seems to have a major influence on the organization of the new urban space by tourism. Revitalized, former central industrial areas with original architectural features and old industrial buildings are intended to be new tourism destinations and can be recognized as new urban and tourism spaces. Their type will depend on long-term urban policy. The purpose of this work is not the identification of all types of tourism space, but indicating the role of the revitalization of degraded urban areas in shaping new urban and tourism spaces and transforming existing ones.

Thus the research issue is presented as being in the mainstream of research on tourism space (LISZEWSKI 2005, WŁODARCZYK 2007). According to a definition presented by WŁODARCZYK (2007), the presence of tourism is a necessary and sufficient condition for the classification of geographical space as a tourism space. While, the size and nature of tourism development allows the type of this space to be specified more accurately (LISZEWSKI 1995, WŁODARCZYK 2006 and 2007).

\section{CASE STUDY OF MANCHESTER}

Manchester is a city of Roman origin. Its genesis goes back to $79 \mathrm{AD}$, when at the confluence of the Rivers Irwell and Medlock a castrum was established with the name Mancunium or Mamucium (historians use both versions). The Roman settlement collapsed in the $5^{\text {th }} \mathrm{c}$. and the main core moved north to the vicinity of the confluence of the Irwell and Irk. The medieval town developed on the right bank of the Irwell where in the $15^{\text {th }}$ c. the parish church (now a cathedral) was substantially extended (Fig. 1), and along Deansgate Street which is a relic of a Roman trade route leading north and constitutes the main urban axis connecting the original and medieval settlements. Along with intensive industrialization since the $17^{\text {th }} \mathrm{c}$., the mainly commercial Manchester central area consisted of numerous industrial zones located primarily to the south of the medieval core (Fig. 1).

Although Manchester is known as the 'first industrial city in the world' and the 'industrial jewel in the British crown', it was not a typical manufacturing town (KIDD 1993). It was once the world centre of trade in the textile industry which involved the presence of numerous storage facilities in the central area. In the $20^{\text {th }} \mathrm{c}$. the city suffered from the economic and social crises connected with the collapse of the industry. The first symptoms appeared in the 30's (KIDD 1993), and its culmination was in the 60's (LisZEWSKI \& YOUNG 1997, KACZMAREK 2001). A wide range of industrial sites in the city centre and its outskirts became subject to rapid degradation, a process accompanied by the 'devalorization' 2 of the whole central area of Manchester. The first recovery programs were undertaken in the $80^{\prime}$ s, whereas the last decade of the $20^{\text {th }} \mathrm{c}$. was characterized by an intensive revitalization of industrial wasteland, coordinated with modernization throughout the city centre (KACZMAREK 2001, PECK \& WARD 2002).

Along with the spatial and functional transformations in central Manchester, the material heritage of the industrial era was highlighted in the modernized urban space. Former industrial facilities have been renovated and adapted to new functions, including tourism, which seems to constitute a crucial quality for the new urban landscape. Revitalized former industrial facilities are unevenly concentrated, most are located along the canals in the southern part of the central area in the areas of Castlefield, the City Centre itself, Gaythorn, Whitworth and Piccadilly. In the first of these areas, many former industrial sites are preserved in new types of integrated urban development. Because of its 'cognitive' value, which also has a reconstructed Roman castrum, it is called the 'cradle of Manchester' (KACZMAREK 2001). The leading feature 


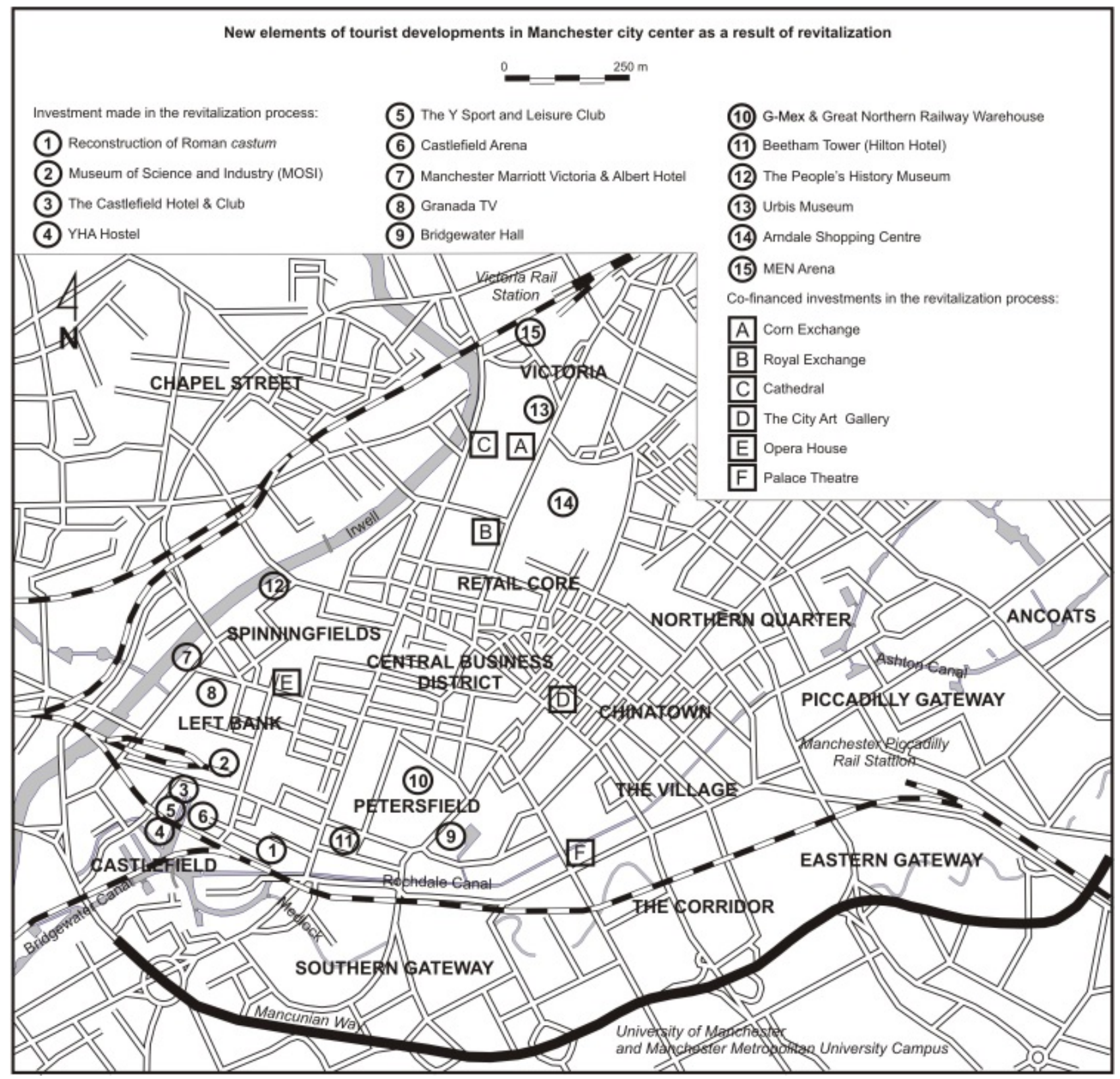

Fig. 1. Development of tourism in the centre of Manchester S o u r c e: authors own work

was to be tourism, nonetheless, residential and recreational functions were added too. In Castlefield, all former industrial buildings with historical value became subject to revitalization, and in 1982 the first Urban Heritage Park in Great Britain was created (GIBSON 1997). In the context of the 'cognitive' development of tourism in the area, the greatest importance was attached to the adaptation of the world's first railway station Liverpool Road (from 1830), into a Museum of Science and Industry (MOSI) (see no 2. on Fig. 1). Here one may learn about the industrial revolution, the structure and operation of steam engines, locomotives, mills, the first electric machines and printers. The location was chosen for the sake of the rich history associated with the industrial revolution and the unique architecture of the region. In the vicinity of the museum there are also tourism sites such as the Castlefield Hotel \& Club (Fig. 1 - no 3 ), youth hostel (YHA) (no 4), sport and recreation centre (Y Sport and Leisure Club) (no 5), and Castlefield Arena (no 6) modelled on the Roman amphitheatre. Behind it, to the east, there are the foundations of the Roman castrum surrounded by reconstructed defensive walls (no 1). On the western edge of Castlefield across the Irwell river a four-star hotel, is the Manchester Marriott Victoria and Albert (no 7), 
funded by a regional media company - Granada TV (no 8). What is more, its recording studios are available to explore (Fig. 1).

An integrating element of all the former industrial areas which have undergone revitalization, are the Bridgewater and Rochdale canals. Alongside these canals are towpaths with numerous benches and green spaces encouraging rest. Consequently, in the zones known as waterfronts (areas where the city has contact with water) attractive public spaces have been created. Moreover, along the banks of the canals (in Castlefield called Castle Quays), there is a wide range of cafes and restaurants located in former warehouses and depots formerly connected to the waterways. They were used for the storage of raw materials and also finished products which were then exported through the port in Liverpool, and later through the port of Salford too. Other gastronomic locations have emerged under railway arches or in new buildings with a characteristic style which refers to the past, constituting a dominant feature of the landscape and the subsequent 'cognitive' tourism value of this part of Manchester. Along with the process of revitalization, the canal has been cleaned and is used today as a popular tourism water route. At its edge, there are numerous moored boats used by individual tourists. The Bridgewater Canal, and the Manchester Ship Canal (west of Manchester, with its outlet in the port of Liverpool), is an important part of one of the longest canal systems in the north west of England, consisting of the northern - Rochdale Canal, and the southern - Ashton Canal. The Ashton and Rochdale canals merge in the area around Manchester Piccadilly Railway Station and are located latitudinally through the entire southern part of central Manchester. Today all are navigable. This system of canals, along with the small River Medlock, is a linear element interconnecting the renewed former industrial wastelands. Elements of the original development of industrial areas do not dominate the urban landscape, but form an important and integral part. Revitalization involved the location of flagship projects whose purpose was to give impetus to further spatial and functional transformations within urban units (BIANCHINI et al. 1992, PECK \& WARD 2002). In the 1990s, revitalization led to the building of the Bridgewater Hall in 1996 (no 9) in the city centre itself where metropolitan functions were expected to play a dominant role. In addition, the former Central railway station was converted into the G-Mex conference and exhibition centre (1986) (no 10). In its vicinity there is also the Great Northern Railway Warehouse (no 10) which includes a multi-storied car park and an entertainment centre. Nearby, there is the highest skyscraper in the city which houses apartments and the Hilton Hotel (no 11), the highest
(169 m) residential building in Great Britain outside London, and constituting an integral part of the urban landscape. The skyscraper is an iconic feature of Manchester and its new metropolitan image. Clearly, it constitutes one of the attractions of the city, whereas, the Hilton Hotel upgrades the standard of accommodation (Fig. 1).

Further flagship projects increasing the attractiveness of Manchester, realized in the framework of spatial and functional transformation, are the People's History Museum (previously - National Museum of Labour History) in the area of Spinningfields (no 12), and Urbis (the former Centre for Urban Culture) (no 13) in the vicinity of the cathedral (Fig. 1 symbol C), the Corn Exchange (A), Arndale shopping centre (no 14) and Victoria Railway Station (Fig. 1). They are located in areas which were not directly occupied by industry, consequently, their architecture does not refer to the city's industrial past. Among other important cultural institutions, Manchester Museum deserves special attention as there is a significant collection of the Egyptian art, as well as the City Art Gallery (D). Both institutions have received financial support in the process of the revitalization of the centre of Manchester (from the National Lottery) for the renovation of the buildings. These places, along with the Gallery of English Costume at Platt Hall, the Police Museum, the Museum of Transport, Palace Theatre (F), the Opera House (E) and others, create an unusual cultural offer. The flagship project also completed the development of various sports sites, for example the sports arena (Manchester Evenings News (MEN) Arena, previously known as Nynex - Fig. 1 no 15), the Manchester Velodrome at the National Cycling Centre, and the City of Manchester football stadium, designed for the Olympic Games in 2000 which ultimately were not held in Manchester, however it was used for the Commonwealth Games which took place in 2002. These sites, as well as the events held in their interiors (concerts, exhibitions, sports events), have significantly diversified the tourism offer of the city. Moreover, Manchester was a host city in the European Football Championship (Euro 1996) while in 1994 it had received the prestigious title 'City of Drama'. These events and others have influenced the process of creating a new brand for Manchester.

Another type of urban space undergoing spatial and functional transformation is the Northern Quarter, located to the north-east of the commercial core of the city (Fig. 1). This district has retained the most original industrial landscape in Manchester whose characteristic feature was the mosaic of different building types and functions, which to some extent has been preserved into modern times. Nowadays, intensive implementation of the residential function 
can be observed in this area, reflected in the increasing number of apartment buildings. Due to its peripheral location in relation to the city centre and lack of metropolitan amenities, this zone is not a popular tourism destination. Nonetheless, it is visited by artists, young people and individual tourists because of its unique architecture and atmosphere.

To sum up, it can be observed that former industrial sites located in a small area, have been almost entirely adapted to the tourism function sensu stricto, for example MOSI, and sensu largo - canals and the entire Castlefield district. Revitalization of this area was connected with the location of recreation areas and numerous other sites which constitute a tourism profile. At the same time, elements of urban structure such as trade or mass entertainment, were not accepted here, as they would dominate the 'cognitive' structure of Castlefield. Tourism gives an opportunity to explore technological and communication sites, such as canals and railway bridges, as well as the preserved industrial architecture which has undergone a contemporary facelift. In other parts of central Manchester, where the former industrial sites are located at specific sites, spatial and functional transformations have involved adaptation of these sites within the context of a particular urban area. Nevertheless, no attempt was made to interfere with their architectural form. Thus, historic former industrial buildings remain an important part of the urban landscape, a permanent mark of identity for the citizens of Manchester. Some of these buildings have become the most important tourism attractions of the city, likewise, other sites were constructed because of the revitalization of former industrial areas (Table 1). Their location in previously isolated urban areas and as part of the newly established tourism base, have contributed to generating new tourism space in Manchester.



Fig. 2. Foreign tourists in Manchester: 1999-2010 S o u r c e: Author's own research based on International Passenger Survey, Office for National Statistics

The great importance of revitalization process for shaping new tourism attractions of the city is reflected in the volume of tourism which has been increasing since the 1990s and in the first decade of the $21^{\text {st }} \mathrm{c}$. (Fig. 2). The case of Manchester demonstrates that industrial wasteland revitalization has initiated the formation of new tourism space and modified the existing area, whilst the transformation of degraded urban areas has enabled tourism facilities to emerge on the foundations of a central area which was

T a b l e 1. The most popular tourism attractions in Greater Manchester by visitor numbers: 2004-9

\begin{tabular}{|c|c|c|c|c|c|c|}
\hline Places of tourism interest & 2004 & 2005 & 2006 & 2007 & 2008 & 2009 \\
\hline MOSI (R) (2) & $469399(1)$ & $430794(2)$ & $392361(2)$ & $704975(2)$ & $852262(1)$ & 532763 \\
\hline Manchester Art Gallery (RF) (D) & $291066(3)$ & $262961(4)$ & $345850(3)$ & $393650(3)$ & $394205(3)$ & 408539 \\
\hline $\begin{array}{l}\text { Bolton Museum, Aquarium and } \\
\text { Archive }\end{array}$ & $227289(7)$ & $271462(3)$ & $257343(4)$ & $267483(4)$ & $309865(5)$ & 374079 \\
\hline Manchester United FC Museum & $232831(6)$ & $219332(7)$ & $219496(9)$ & $263325(6)$ & $326654(4)$ & 309397 \\
\hline Urbis (R) (13) & $193798(8)$ & $173905(10)$ & $256240(5)$ & $251540(6)$ & $262114(6)$ & 253041 \\
\hline Runway Visitor Park & $264743(4)$ & $248514(5)$ & $250000(6)$ & $226087(8)$ & $228000(9)$ & 241000 \\
\hline IMWN (R) & $249875(5)$ & $229968(6)$ & $235991(7)$ & $222791(9)$ & $238794(8)$ & 236529 \\
\hline
\end{tabular}

K e y: R - new site, result of revitalization, RF - existing site within the industrial wasteland revitalization program, (2) site symbol in Fig. 1, (2) - position in tourism attraction ranking (by year).

S o u r c e: author's own research based on Greater Manchester Tourism Facts \& Figures. 
previously dominated by trade (including Arndale, Urbis and MEN Arena) and services (People's History Museum in Spinningfields).

\section{CASE STUDY OF LYON}

Lyon, in common with Manchester, is of Roman origin. The first settlement of Lugdunum was located on Fourvière hill in 43 B.C. (Fig. 3). After the collapse of the Roman Empire it was abandoned and subsequent settlements were situated lower down by the Saône River, and later on the peninsula between the Saône and the Rhône. Development of the $19^{\text {th }} \mathrm{c}$. city involved expansion on the left bank of the Rhône, the period of Lyon's greatest industrialization.

Lyon is the biggest historical centre of the textile industry in France and in the past the literature often referred to it as 'the world's capital of silk'. Unlike Manchester, Lyon's textile industry has never dominated the city's social and economic structure (STRASZEWICZ 1987) while former industrial sites are also significantly less visible in the present cityscape. The biggest post-industrial zone in the central area, Confluence, has an area of 150 ha, is situated in the southern part of the Presqu'île peninsula, well south of Place Bellecour, between the Saône and Rhône which converge at its southernmost point (Fig. 3). This part has never been occupied by the textile industry unlike the revitalized industrial wasteland in Manchester described above. However, Confluence played the key role in the development of Lyon's textile industry because since the 1830s a multi-modal communication hub has developed there, with river docks, a railway, and an unloading point for coal which was imported from the Loire which constituted the main energy resource for Lyon's factories. The railway contributed to a reduction in the cost of importing coal from farther regions in France and, in consequence, to reducing the production cost and increasing the competitiveness of Lyon's textile industry products. Apart from coal storage facilities, the area of Confluence was occupied by locomotive, chemical and tobacco factories as well as power stations. Moreover, two remand centres and a postal sorting office were situated here. The northern part of this zone, an area of 40 ha with residential and trading functions, is the art nouveau district of Saint-Blandine.

Confluence was formed in the 1770 s as a result of the regulation of the banks of the Saône and Rhône. Earlier Ile Mogniat and other smaller islets were found here. The appearance of Confluence, undeveloped land in the heart of the city provided new challenges for planners. After the beginning of the industrial era this area was given an industrial function which was exogenic and developing. In the early years of the $19^{\text {th }}$ c. an industrial landscape dominated the area. However, in the second half of the $20^{\text {th }} \mathrm{c}$. this district began to lose its significance due to the collapse of industry. An additional factor contributing to Confluence's isolation from the rest of the city was the location of Gare de Lyon-Perrache in 1855 which separated it from the northern part of Presqu'île. The area was then called 'derrière les voûtes' (behind the arches) by citizens and treated as remote, unknown, hostile or even dangerous (COUDROY DE LILLE 2003).

This negative attitude was intensified by the location of a new communication hub in the 1970s with an international coach station alongside the railway station, and then by the building of a motorway (Fig. 3) which involved the total demolition of existing buildings and the isolation of Confluence from the rest of the city. In its southern part, the district is linked to the rest of the city by motorway and railway bridges both unavailable to pedestrians. There is only one crossing nowadays, Pont Pasteur, across the Rhône to the Gerland district (Fig. 3).

The revitalization process aims to restore the accessibility of this zone as well as to engage its space with an attractive range of services. This is intended to expand the functions of the historical city centre in Presqu'île, which was placed as a whole on the UNESCO World Heritage List in 1998. This area with its Croix-Rousse district and Fourvière hill where the Roman castrum was located and a Roman amphitheatre is still preserved, is of the greatest tourism interest (Fig. 3). However, the industrial monuments in Lyon present less value for visitors as expressed by the actions of the city authorities and their manner of revitalizing the industrial wasteland in Confluence. Spatial and functional changes in this district include most often replace old factory facilities with new buildings, but unlike Manchester these buildings are rarely designed for tourism purposes. In Confluence it is planned to build:

- apartment houses ('Saône Park', 'Lyon Islands', Le Monolithe) (see nos 1, 2, 3, on Fig. 3);

- marinas (in Rambaud dockland) (see no 4);

- a shopping and leisure centre (Pôle de loisirs with a flagship project - projets phares - 'the lighthouse') (see no 5);

- an art gallery and a museum (Musée des Confluences - a flagship project) (see no 8);

- a sports and recreation centre (see no 9);

- hotels of various ratings (see nos 6, 16).

A new public space including new streets, a park (Parc Saône), two squares (Place des Archives and Place Nautique) and a pedestian area within the marina (see nos 4, 10, 11, 12 on Fig. 3) will also be developed.

The investments mentioned above are situated in the south-western part of Confluence which was 


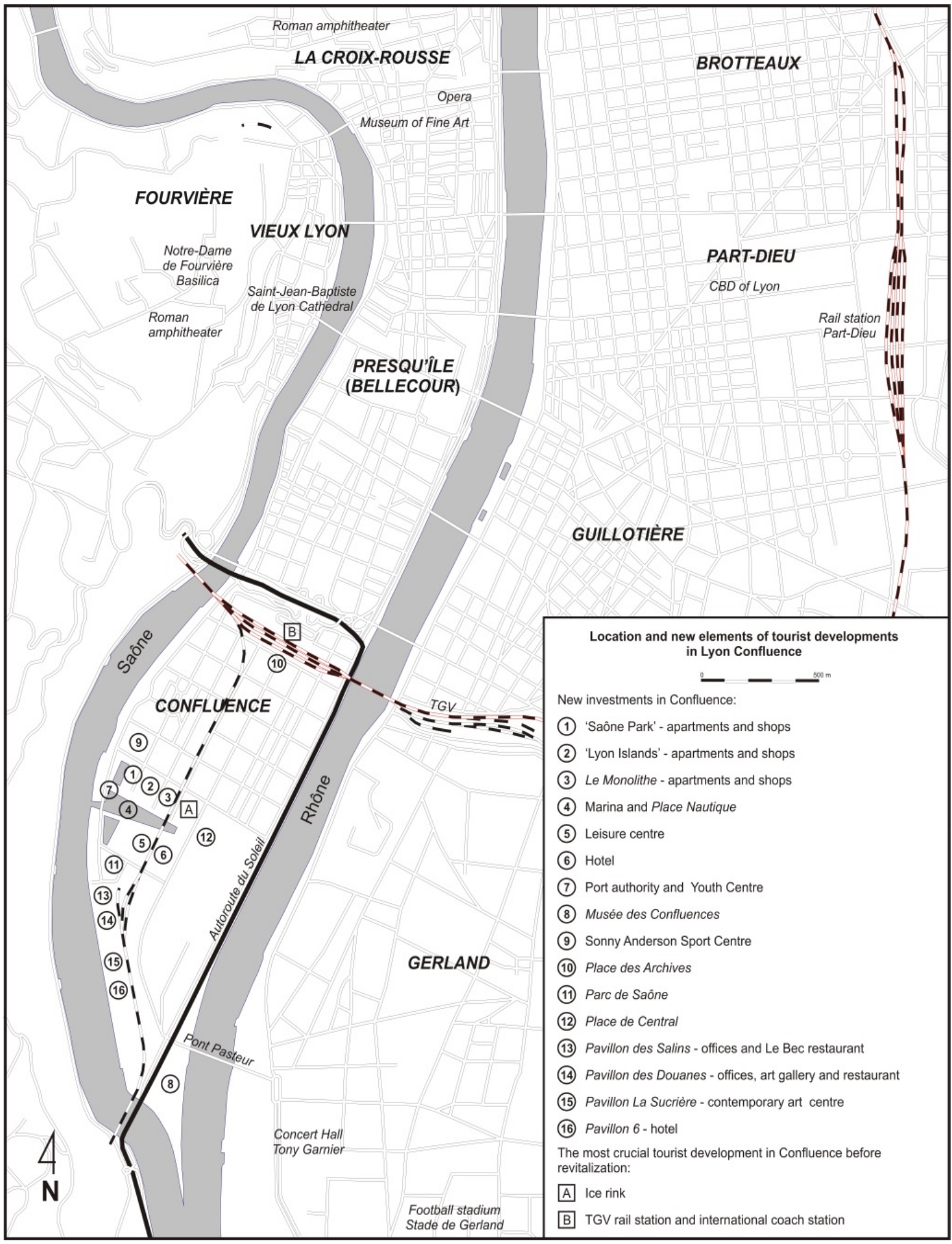

Fig. 3. Location and tourism development of Lyon Confluence S o u r c e: authors own work

originally industrial but spatial and functional changes in this district have resulted in the almost total demolition of industrial buildings. Presently only railway yards in the centre of the peninsula and storage facilities in the south remain. As a result of revitalization almost the whole of the Saône embankment has been given a new architectural and urban shape while the Rhône bank remains isolated because of the motor- 
way (the famous Autoroute $d u$ Soleil). Some pedestrian bridges crossing the rivers are part of urban plans to increase its accessibility from other parts of the city.

The spatial and functional changes in Confluence will entirely transform this part of Lyon's cityscape depriving it of industrial architecture and replacing it with modern buildings confirming the metropolitan nature of the city. Industrial facilities are practically invisible in other regions of the city. Revitalization of this district does not entail modernization in other parts of Lyon as in Manchester (with a scattering of flagship projects in the historical city centre). The transformation of Confluence will give the area the character of an 'Urban Entertainment Centre' providing cultural, leisure, shopping and gastronomic services. According to Tölle (2006) facilities of this type are the result of the increasing importance of the leisure industry accompanying the decline of traditional department stores in western countries.

The main reason for the lack of interest in the promotion of industrial history monuments in today's urban policy is Lyon's position on the UNESCO World Heritage List which has already secured its prestige and position on the national tourism map. Contrary to the revitalization in Manchester, the develoment process of Lyon's wasteland has almost entirely eliminated any remains of the industrial era. Remaining sites in the south-eastern part of Confluence and in Gerland are decaying or being replaced with modern city building, only a few have been adapted to new functions. Thus the citizens of Lyon have been deprived of a part of their identity and the cityscape is incomplete, lacking an essential part of its history.

The area of Confluence has functions satisfying basic needs and raising the standard of life. The location of cultural, entertainment and shopping facilities could expand the area of tourism interest which is now concentrated in the city centre. What is more, the building of a large hotel next to the shopping and entertainment centre as well as several smaller hotels will enlarge the city's accommodation offer as the centre is over-provided for and restricted by UNESCO World Heritage regulations, an obstacle to any hotel investment. Undoubtedly sites generated within the industrial wasteland revitalization program will increase Confluence's tourism attractiveness despite the elimination of the industrial facilities that gave rise to the area. Revitalization in Lyon can be regarded as a process aiming to expand existing tourism space and reflected in numerous tourism and para-tourism investments in the area. As there have been no surveys of tourism in Confluence so far, it is hard to estimate its present extent and its significance on the scale of the city as a whole.

\section{CONCLUSION}

Comparative studies of the two post-industrial cities has demonstrated that the extent of preservation and exhibition of material parts of their historical legacies in the cityscape, as well as their contribution to tourism purposes. It can also be claimed that the revitalization of land which was previously used for industry has various influences on shaping a city's tourism space and depends on the role which local authorities allocate to tourism (especially tourism on industrial and former industrial sites) and their policy of allocating a tourism function to this newly recovered area.

Lyon is a historical city with a rich 'tourism biography' and a complex range of metropolitan facilities that attract visitors. That is why the spatial and functional transformation of the central area has not significantly contributed to creating new or modifying existing tourism space. On the other hand Manchester had no specific tourism space for a long period of its history because of the domination of industry in the cityscape and the poorly developed central area. Tourism space in Manchester appeared as a result of increasing interest in the industrial era as it became regarded as an important stage of civilization and as such aroused great curiosity in visitors. In this way the hidden tourism potential of the city was revealed and then used mainly for 'cognitive' tourism purposes thanks to the adaptation of the industrial buildings into modern tourism facilities. This process was accompanied by larger scale economic and social transformations which have shaped the present metropolitan cityscape.

Industrial wasteland revitalization, city centre modernization and other activities (such as promotion of the city's new image, flagship project realization and hosting renowned events) have been possibly the only chance to establish a position for Manchester on the tourism map. The source of the city's image profit ${ }^{4}$ was in this case the consistently realized policy of the authorities and accompanying marketing campaigns. This is the so-called created image profit whereas Lyon is an example of the so-called inherited image profit $^{5}$. KACZMAREK (2010) claims that a negative image of a city constitutes a threshold for its development (see Boleslaw Malisz's concept of settlement evolution and development thresholds). Therefore it can be assumed that through industrial wasteland revitalization Manchester city council made the necessary contribution to cross over this boundary and support social and economic development. As a result this a development-influenced progression attracted new investments. These factors are, for example, environmental quality, living standards and 
an attractive cultural and tourism offer. Everything mentioned above enhances tourism attractiveness and shapes the urban tourism space. In Manchester, revitalization is a factor creating a new tourism space while in Lyon it changes the present cityscape by expanding the city's tourism offer thanks to new institutions and facilities that stimulate both typical and innovative behaviour of its visitors.

This issue seems to be of vital importance not only in a western European context but also because of the extent of degradation in Polish cities (ZIOBROWSKI \& JERCZEWSKI 2009) and increasingly intensive central area revitalization processes on former industrial land. It is a common situation that such areas adjoin a historical city centre that is a traditional tourism space. For this reason connections between revitalization and tourism development should be subject to empirical research. This would then contribute to further discussion and attempt to provide contemporary tourism space research with an approach concentrated on spatial transformation from a perspective of industrial wasteland revitalization.

\section{FOOTNOTES}

${ }^{1}$ Publication co-financed by the European Social Fund and State Budget - 8.2.1. Operational Program 'Human Resources Development', in connection with 'Doctoral Students' project Regional Investment in Young Scientists - Acronym D-RIM'.

2 'Devalorization' - decrease in the value of something (author's translation; from Stownik jezzyka polskiego, part 1, ed. M. Szymczak, PWN, Warszawa 1978).

${ }^{3}$ Image profit - the economic value of a city's image, i.e. the profit generated by its actual or created positive image. It should sustain an additional income for citizens and investors making use of the positive perception of the city (KACZMAREK 2010, s. 36).

4 Created image profit - consistently performed marketing actions of the authorities which lead to a positive image of the city (ibidem).

${ }^{5}$ Inherited image profit - additional value that results from a positive historical image of a city (ibidem).

\section{BIBLIOGRAPHY}

BIANCHINI F., DAWSON N, EVANS P., 1992, Flagship Projects in Urban Regeneration, [in:] P. Healy, S. Davoudi, M. O'Toole, S. Tavsanoglu, D. Usher (ed.), Rebuilding the City: Property-led Urban Regeneration, E. \& F. N. Spon, London.

BRADBURY N., 1993, The Role of Tourism in Urban Regeneration: Castlefield, Manchester U.K. Materiały pokonferencyjne I.N.T.A. Conference, Fort Lauderdale, U.S.A.

COUDROY DE LILLE L., 2003, Lyon Confluence - metropolitalny projekt w widłach Rodanu i Saony w Lyonie, [in:] I. Jażdżewska (ed.), Funkcje metropolitalne $i$ ich rola $w$ organizacji przestrzeni, XVI Konwersatorium Wiedzy o Mieście, Wyd. UŁ, Łódź, pp. 267-275.

DEWAILLY J. M., 1996, L'espace tourismique: du réel au virtuel, 28é Congéssur la Géographie, La Haye (Pay-Bas), pp. 17.
DOMAŃSKI B., 2000, Restrukturyzacja terenów poprzemysłowych w miastach, [in:] Z. Ziobrowski, D. Ptaszycka-Jackowska, A. Rębowska, A. Geissler (ed.), Odnowa miast. Rewitalizacja, rehabilitacja, restrukturyzacja, Instytut Gospodarki Przestrzennej i Komunalnej, Wyd. Politechniki Śląskiej, Gliwice.

GASIDŁO K, 1998, Problemy przekształceń terenów poprzemystowych, Wyd. PŚ, Gliwice.

GIBSON CH., 1997, The Role of Tourism in Restructuring Region and the Creation of a New Image of the City in Manchester, [in:] S. Liszewski, C. Young (ed.), A Comparative Study of Łódź and Manchester. Geographies of European Cities in Transition, Wyd. Uniwersytetu Łódzkiego, Łódź, pp. 263-277.

IMRIE R., THOMAS T., 1993, British Urban Policy and the Urban Development Corporations, Paul Chapman Publishing, London.

KACZMAREK J., 2010, Zarządzanie wizerunkiem miasta - uwagi heurystyczne, [in:] J. Słodczyk, E. Szafranek (red.), Studia Miejskie 1. Koncepcje i instrumenty zarzadzania procesami rozwoju i rewitalizacji miast, Uniwersytet Opolski, Opole, pp. 2938

KACZMAREK S., LISZEWSKI S., 1997, The Role of Tourism in the Restructuring of the Łódź region and in Creating a New Image of the City, [in:] S. Liszewski, C. Young (ed.), A Comparative Study of Łódź and Manchester. Geographies of European Cities in Transition, Wyd. Uniwersytetu Łódzkiego, Łódź, pp. 249-261.

KACZMAREK S., 1997, Kreowanie wizerunku miasta poprzemysłowego na przykładzie Glasgow i Łodzi, [in:] T. Domański (ed.), Marketing terytorialny. Strategiczne wyzwania dla miast $i$ regionów, Wyd. Centrum Badań i Studiów Francuskich UŁ, Łódź, pp. 167-174.

KACZMAREK S., 2001, Rewitalizacja obszarów poprzemystowych. Nowy wymiar w rozwoju miast, Wyd. Uniwersytetu Łódzkiego, Łódź.

KIDD A., 1993, Manchester, Ryburn Publishing. Keele University Press, Manchester.

KOWALCZYK-ANIOŁ J., 2006, Rozwój przestrzeni urlopowo-wakacyjnej tódzkich rodzin na przyktadzie studentów Uniwersytetu Łódzkiego i ich rodzin, Wyd. ŁTN, Łódź.

LATOSIŃSKA J., 2006, Przestrzeń turystyczna - jedno pojęcie dwa znaczenia. Rozważania na temat indywidualnej przestrzeni turystycznej, Turyzm, 16/2, pp. 93-98.

LISOWSKI A., 2003, Koncepcje przestrzeni w geografii człowieka, Uniwersytet Warszawski, Wydział Geografii i Studiów Regionalnych, Warszawa.

LISZEWSKI S., 1995, Przestrzeń turystyczna, Turyzm, 5/2, pp. 87103.

LISZEWSKI S., 1999, Przestrzeń turystyczna miasta (przykład Łodzi), Turyzm, 9/1, pp. 51-72.

LISZEWSKI S., 2005, Przestrzeń turystyczna w ujęciu podmiotowym. Przyczynek do dyskusji o przestrzeni w geografii, [in:] Podstawowe idee $i$ koncepcje w geografii, t. 1 - Geografia jako nauka o przestrzeni, środowisku i krajobrazie, Wyd. ŁTN, Łódź, pp. 50-60.

LISZEWSKI S., 2006a, Nowe przestrzenie turystyczne i rekreacyjne $\mathrm{w}$ Polsce i ich rola $\mathrm{w}$ rozwoju kraju i regionu, [in:] G. Gołembski (ed.), Turystyka w ujęciu podmiotowym i przestrzennym. Człowiek - Przestrzeń - Przedsiębiorstwo, Wyd. Akademii Ekonomicznej w Poznaniu, Poznań 2006, pp. 113-125.

LISZEWSKI S., 2006b, Przestrzenie turystyki i transformacja we współczesnym świecie, Turyzm, 16/2, pp. 7-19.

LISZEWSKI S., 2009a, Przestrzeń turystyczna Polski. Koncepcja regionalizacji turystycznej, [in:] I. Jażewicz (ed.), Wspótczesne problemy przemian strukturalnych przestrzeni geograficznej, Wyd. Naukowe Akademii Pomorskiej w Słupsku, Słupsk, pp. 59-69. 
LISZEWSKI S., 2009b, Przestrzeń turystyczna parków narodowych w Polsce, [in:] B. Domański, W. Kurek (ed.), Gospodarka i przestrzeń, Instytut Geografii i Gospodarki Przestrzennej Uniwersytetu Jagiellońskiego, Kraków, pp. 187201.

LISZEWSKI S., 2009c, Przestrzenie turystyki i osadnictwo turystyczne, [in:] G. Gołembski (ed.), Kompendium wiedzy o turystyce, Wydawnictwo Naukowe PWN, Warszawa, pp. 95-128.

LISZEWSKI S., 2009d, Miejska przestrzeń eksploracji turystycznej. Przykład Łodzi (Urban 'Tourism Exploration Space': The Example of Łódź), Turyzm/Tourism, 19/1-2, pp. 59-65 (57-62).

LISZEWSKI S., BACHVAROV M., 1998, Istota i właściwści przestrzeni rekreacyjno-turystycznej, Turyzm, 8/1, pp. 39-67.

LORENS P., 2005, Wstępna typologia obszarów zdegradowanych o funkcjach i potencjale metropolitalnym, [in:] T. Parteka (ed.), Transformacja zdegradowanych struktur przestrzennych metropolii polskich, KPZK PAN, Warszawa, pp. 57-74.

LORENS P., 2007, Rewitalizacja miast w Polsce: pierwsze doświadczenia, „Urbanista', Warszawa.

LORENS P., 2010, Rewitalizacja miast. Planowanie i realizacja, Wyd. Politechniki Gdańskiej, Gdańsk.

LORENS P., MARTYNIUK-PĘCZAK J. (ed.), 2009, Wybrane zagadnienia rewitalizacji miast, ser. Miasto. Metropolia. Region, Wyd. Urbanista, Gdańsk.

Lozato-Giotart J. P., 2003, Géographie du tourisme, De l'espace consommé à l'espace maîtrisé, Pearson Education.

MARKOWSKI T., STAWASZ D. (ed.), 2007, Rewitalizacja a rozwój funkcji metropolitalnych miasta Łodzi, Wyd. UŁ, Łódź.

MEYER B., 2004, Turystyka jako ekonomiczny czynnik ksztattowania przestrzeni, Uniwersytet Szczeciński, Rozprawy i Studia (DCXIX) 545, Szczecin.

MiossEC J. M., 1976, Elements pour une teorie de l'espace tourismique, Centre des Hautes Etudes Tourismiques, serie C, 36, Aixen-Provence.

MiRONOWICZ I., OssowICZ T., 2005, Metodologia badania degradacji obszarów o funkcjach metropolitalnych, [in:] T. Parteka (ed.), Transformacja zdegradowanych struktur przestrzennych metropolii polskich, KPZK PAN, Warszawa, pp. 36-56.
OPPERMANN M., 1993, Tourism space in developing countries, Annals of Tourism Research, 20(3), pp. 535-556.

PECK J., WARD K. (ed.), 2002, City of Revolution. Restructuring Manchester, Manchester University Press, Manchester.

PRZYBYSZEWSKA-GUDELIS R., 1997, Problemy rewitalizacji miast przez turystykę, [in:] Kulturowe aspekty turystyki i gospodarki turystycznej, Polskie Stowarzyszenie Turystyki, Warszawa, pp. 17-26.

STALSKI M., 1984, Użytkowanie ziemi w turystyce, Przeglad Zagranicznej Literatury Geograficznej, 2, pp. 139-148.

STRASZEWICZ L., 1987, Lyon - przemiany wielkiej metropolii regionalnej Europy Zachodniej, Acta Universitatis Lodziensis, Folia Geographica, 8, Łódź, pp. 131-163.

TÖLLE A., 2006, Kształt i funkcje nowych kwartałów śródmiejskich na obszarach nadwodnych. Francusko-niemiecko-polskie porównanie, [in:] I. Jażdżewska (ed.), Nowe przestrzenie $w$ mieście ich organizacja i funkcje, Wyd. Uniwersytetu Łódzkiego, Łódź, pp. 193-200.

VIRÁNYI Z. G., 2010, Urban Renewal in Lyon Confluence. How to transform an unused industrial area into the new eco-quarter?, VIA University College, Horsens, Danmark.

WARSZYŃSKA J., JACKOWSKI A., 1978, Podstawy geografii turyzmu, PWN, Warszawa.

WŁODARCZYK B., 2006a, Cycle of Development of the tourism space, [in:] Tourism and regional development, Smolensk, pp. 225-234.

WŁODARCZYK B., KACZMAREK J., STASIAK A., 2005, Produkt turystyczny, Wyd. PWE, Warszawa.

WŁODARCZYK B., 2006b, Przestrzeń turystyczna - cykliczność, "aktorzy', determinanty rozwoju, Turyzm, 16/2, pp. 41-64.

WŁODARCZYK B., 2007, Przestrzeń turystyczna - pojęcie, wymiary, cechy, Turyzm, 17/1-2, pp. 145-158.

WŁODARCZYK B., 2009, Przestrzeń turystyczna - istota, koncepcje, determinanty rozwoju, Wyd. Uniwersytetu Łódzkiego, Łódź.

ZIOBROWSKI Z. et al., 2000, Rewitalizacja. Rehabilitacja. Restrukturyzacja. Odnowa miasta, Instytut Gospodarki Przestrzennej i Komunalnej, Kraków.

ZIOBROWSKI Z., JERCZEWSKI W., 2009, Rewitalizacja miast polskich - diagnoza, Instytut Rozwoju Miast, Kraków. 